\section{Influence of Elevating Tree Potassium on Fruit Drop and Yield of Pecan}

\author{
Bruce W. Wood ${ }^{1}$ \\ U.S. Department of Agriculture, Agricultural Research Service, Southeastern \\ Fruit and Tree Nut Research Laboratory, 21 Dunbar Road, Byron, GA \\ 31008-0087
}

\section{Lenny Wells}

Department of Horticulture, University of Georgia, 4604 Research Way, Tifton, GA 31793

\section{Frank Funderburke \\ Department of Horticulture, University of Georgia, Fort Valley, GA, 31030}

Additional index words. Carya illinoinensis, nutrient disorder, deficiency, June drop, flower abortion, quality, kernel quality, fertilizers, management, potash

\begin{abstract}
Excessive Stage II fruit drop (i.e., June drop) often limits profitability of certain pecan [Carya illinoinensis (Wangenh.) C. Koch] cultivars. Anecdotal evidence indicates that one cause of drop is linked to a nutrient element deficiency. This study examines the consequences of improving tree potassium (K) nutrition on fruit drop, nutmeat yield, and kernel quality (i.e., \% kernel) in 'Desirable' orchards in which generally accepted foliar analysis standards indicate satisfactory tree $\mathrm{K}$ nutritional status (i.e., $\mathbf{0 . 7 5 \%}$ or greater to $\mathbf{2 . 5 \%} \mathrm{K} / \mathrm{dry}$ weight). Multiyear field studies of two such orchards found that elevating leaf and fruit $K$ concentration through soil banding of potash over drip irrigation emitters: 1) increased fruit retention by reducing Stage II fruit drop; 2) increased in-shell nut yield; and 3) increased nut quality by increasing percentage kernel. Potash applied through soil banding elevated foliar and fruit $\mathrm{K}$ concentration by $\approx 0.1 \%$ to $0.4 \%$ units within a few months post-application depending on the amount applied; however, the beneficial effects of a single potash soil band application diminished after the first year. A comparison of the $K$ concentration of retained fruit versus abscised fruit during the Stage II fruit drop window found that retained fruit possessed endogenous $K$ concentrations of $1.2 \%$ to $1.7 \%$ (dry weight basis) in one orchard and $1.45 \%$ to $1.9 \%$ in a second orchard, whereas aborted fruit possessed $K$ at $0.65 \%$ to $1.2 \%$ in one orchard and $0.75 \%$ to $1.2 \%$ in a second orchard, respectively, thus establishing $\approx 1.25 \% \mathrm{~K}$ as a "drop threshold" under conditions of this study. The total $\mathrm{K}$ concentration of retained fruit is typically $0.25 \%$ to $0.50 \mathrm{~K} / \mathrm{dry}$ weight greater than dropped fruit. Considerable K-associated late-spring fruit drop can occur in 'Desirable', although early- to midsummer leaf analysis indicates trees were K-sufficient, hence implying that young fruit likely possesses a higher $\mathrm{K}$ requirement than does foliage. These $K$-associated benefits to trees meeting accepted $K$ sufficiency criteria is evidence that $\mathrm{K}$ nutrition management of 'Desirable' pecan merits $r$-evaluation and possibly pecan $\mathrm{K}$ nutrition in general.
\end{abstract}

Pecan orchard profitability is potentially influenced by tree potassium $(\mathrm{K})$ nutritional status with deficiency being common in commercial orchard operations, especially in years with heavy crop loads. The earliest visible symptom of $\mathrm{K}$ deficiency is typically an irregular interveinal chlorosis of the oldest leaflets of shoots; however, there is anecdotal evidence that in the case of Desirable cultivar, an important cultivar suspected of possessing a relatively high $\mathrm{K}$ requirement,

\footnotetext{
Received for publication 4 Mar. 2010. Accepted for publication 27 Apr. 2010.

Mention of a trademark, proprietary product, or vendor does not constitute a guarantee or warranty of the product by the U.S. Dept. of Agriculture and does not imply its approval to the exclusion of other products or vendors that also may be suitable.

${ }^{1}$ To whom reprint requests should be addressed; e-mail bruce.wood@ars.usda.gov.
} 1931; Gossard, 1933; Smith, 1982; Sparks, 1988; Sparks and Heath, 1972; Sparks and Madden, 1985; Yates and Sparks, 1994). Stage II drop (June drop) is the first postpollination drop (Sparks and Madden, 1985) and can be associated with absence of zygotes or structural problems with ovule tis- sues (Yates and Sparks, 1994, 1995) and might also be associated with physiological stresses accentuated by "moderate to heavy" crop loads (Wood et al., 2009). Depending on genotype, this drop is complete within $\approx 3$ to 5 weeks (usually by mid-June) after stigmas of pistillate flowers lose receptivity and fruit begin slow elongation growth before rapid fruit enlargement at the end of the canopy growth phase. Stage III drop appears largely the result of deficiencies in the cellular endosperm, whereas Stage IV drop is associated with retarded embryo development (Yates and Sparks, 1995). In the case of Desirable cultivar, and most other drop-prone genotypes, it is Stage II drop that is most problematic; however, Stage II drop is beneficial in certain years for mitigating severe shuck decline, poor kernel quality, and low return flowering problems (Sparks et al., 1994; Worley, 1995).

There is also evidence, based on ${ }^{14} \mathrm{C}$ allocation in elongating shoots that growth and development of the terminal positioned fruit is impeded when assimilate reserves are low (Lockwood and Sparks, 1978). Thus, one or more endogenous resources appear to contribute to pistillate flower abortion with the effect being greatest in "off" years, when shoot vigor is usually low. Abscised fruit during Stage II fruit development are typically smaller than retained fruit and show no evidence of ovary tissue necrosis (Yates and Sparks, 1994, 1995).

Observations indicate that relatively low potassium $\left(\mathrm{K}^{+}\right)$concentration, based on leaf analysis, of what appear to be well-managed 'Desirable' orchards, often exhibit excessive Stage II fruit drop (i.e., many peduncles having lost $75 \%$ to $100 \%$ of their fruit) and lower than expected nut yields, thus leading the authors to postulate that insufficient K nutrition during early stages of fruit development is a contributing cause of Stage II drop. This postulate is further supported in that 1) there is rapid accumulation of $\mathrm{K}^{+}$in tree organs after bud break; 2) $\mathrm{K}$ is the dominate metal in pecan fruit, especially in shuck (involucre) tissue in which its concentration increases up to eightfold during fruit enlargement (Sparks, 1985 ); and 3) there is evidence for a physiological stressor, perhaps a mineral nutrient, contributing to drop in "moderate to heavy" crop load trees (Wood et al., 2009). The present study examines whether increasing tree $\mathrm{K}$ can reduce Stage II fruit drop and subsequently increase tree nutmeat yield and quality. We report that in certain cases, increasing $\mathrm{K}$ can reduce Stage II fruit drop and improve tree nutmeat yield and quality. Additionally, $\mathrm{K}$ nutritional stress of developing fruit is a factor potentially affecting profitability of trees otherwise thought to be K-sufficient.

\section{Materials and Methods}


exhibiting excessive Stage II drop. One is $\approx 25$ years old (on an 'Elliott' rootstock) and the other is $\approx 40$ years old (on a 'Curtis' rootstock). Both orchards are established primarily on a Faceville sandy loam soil (FoA; fine, Kaolintic, thermic Typic Kandiudult soil) and are located near Byron, GA [lat.

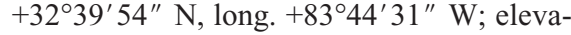
tion $\approx 156 \mathrm{~m}(509 \mathrm{ft})]$. Sites have a freezefree growing period of $\approx 240 \mathrm{~d}$ with annual precipitation of $\approx 1.81 \mathrm{~m}$ (46 inches). Table 1 describes orchard soil chemical characteristics and identifies both orchards as possessing "high" to "very high" amounts of soil K.

The orchard used in Study 1 is spaced $9.1 \mathrm{~m} \times 18.2 \mathrm{~m}(30 \times 60 \mathrm{ft})$ and the Study 2 orchard is spaced $18.2 \times 18.2 \mathrm{~m}(60 \times 60 \mathrm{ft})$. Both orchards are managed according to commercial standards based on Georgia (Hudson et al., 2009) extension service recommendations for pest, fertilizer, and so on, and both receive subsurface drip irrigation with drip emitters rising to the soil surface at $1-\mathrm{m}$ intervals to supplement tree water needs. Two parallel irrigation lines run the length of tree rows positioned $\approx 1.2 \mathrm{~m}$ on either side of tree trunks. Drip emitters delivered water at 3.78 $\mathrm{L} \cdot \mathrm{h}^{-1}$ for $\approx 8$ to $12 \mathrm{~h} \cdot \mathrm{d}^{-1}$ depending on water needs throughout the growing season (irrigation being scheduled through pan evaporation). Irrigation lines are within an herbicide strip maintained in a bare state using two to three glyphosate (Monsanto, St. Louis, MO) applications per year. Trees received annual broadcast applications of nitrogen $(\mathrm{N}), \mathrm{K}$, phosphorous (P), magnesium $(\mathrm{Mg})$, and calcium $(\mathrm{Ca})$ as needed based on previous late July leaf analysis at principal leaf development growth stage "10-11" (Finn et al., 2007). Pest management practices produced nuts with little or no pecan scab damage and little or no fruit drop or fruit damage caused by arthropods.

\section{Experimental design}

Study 1. This orchard possessed a foliar $\mathrm{K}$ concentration that exceeded the level required for avoiding the appearance of visible $\mathrm{K}$ symptoms but substantially less $\mathrm{K}$ than is recommended by the Georgia Extension Service for commercial orchards. Concentration of $\mathrm{K}$ in foliage based on late July leaf analysis averaged $\approx 0.90 \%(0.85$ to 1.0$) \mathrm{K}$ in 2005 , the season before study initiation, yet was not low enough to exhibit standard visual deficiency symptoms.

The treatment variable was continuous and was the amount of potash soil-banded beneath each treated tree. Potash was applied once, in late March 2006, before bud break. The source was $00-00-62$ (i.e., $\mathrm{K}_{2} \mathrm{O}$ at $62 \%$, $\mathrm{Cl}$ at $48 \%$ or less; Royster-Clark, Americus, GA). Potash was applied by concentrating in $\approx 15$-cm wide linear bands spanning several drip irrigation emitters within the herbicide strip beneath both sides of the tree canopy. Potash was applied at $0 \mathrm{X}, 0.25 \mathrm{X}, 0.50 \mathrm{X}, 1 \mathrm{X}$, $2 \mathrm{X}, 3 \mathrm{X}$, and $4 \mathrm{X}$. in which $\mathrm{X}=4.54 \mathrm{~kg}(10$ pounds) of actual $\mathrm{K} /$ tree as potash. The potash was potassium chloride ( $\mathrm{KCl}$; i.e., muriate of potash), a white readily soluble grade commonly used in agriculture. The experimental design was a randomized complete block possessing seven blocks of seven treatments $(n=49)$. Experimental units were single trees blocked based on previous season in-shell yield per tree. Measured parameters were percentage fruit retention at end of Stage II drop (but before Stage III drop): percentage of fruit remaining from the total number of flowers per cluster, in-shell nut yield, kernel percentage, and $\mathrm{K}$ concentration of fruit and foliage in early July (just after conclusion of Stage II drop) in both 2006 and 2008 (2007 data were lost). Trees of the 0X treatment were characterized for fruit drop as to location of drop within the cluster. This was done by counting incidence of basal fruit drop in clusters versus that of apical fruit per cluster on the lower canopy of each of six trees. Fifty nut clusters were counted per tree in late June, after Stage II drop. Test trees did not receive $\mathrm{K}$ fertilizer during the study period except for that provided through treatments.

Study 2. This orchard possessed a foliar $\mathrm{K}$ concentration slightly less than is recommended by the Georgia Extension Service for commercial orchards. Foliar K concentration, based on mid-July leaf analysis, averaged $\approx 1.1 \% \mathrm{~K}(0.95 \%$ to $1.3 \%)$ in 2005 , the season before study initiation.

This study was the same as "Study 1" except 1) potash was broadcast at a rate of
$45.4 \mathrm{~kg}(100 \mathrm{lbs})$ of $\mathrm{K}$ per acre over the entire orchard in 2006, 2007, and 2008; and 2) potash soil banding treatments provided additional potash at $0 \mathrm{X}, 1 \mathrm{X}, 2 \mathrm{X}$, and $4 \mathrm{X}$, in which $\mathrm{X}=10 \mathrm{~kg}$ of actual $\mathrm{K} /$ tree as potash applied once in March 2007; and 3) the experimental design was a randomized complete block of four potash treatments and eight replicates $(\mathrm{n}=32)$. (The experimental unit was a row of trees consisting of 27 to 76 trees.) Measured parameters were percentage fruit drop (assessed at end of Stage II drop), kernel percentage, and $\mathrm{K}$ concentration of mid-July foliage in both 2007 and 2008. Fruit retention (i.e., fruit per cluster, 25 clusters per zone) was counted at both the lower one-third (eastfacing) and upper one-third (east-facing) of the canopy with the aid of binoculars (Steiner Peregrine-XP, $10 \times 44$, Germany) on four randomly selected trees from each experimental unit of each treatment and block. Percentage kernel was derived from a 100-nut sample (air-dried, cracked, and weighed) taken after tree shaking on the same trees from which fruit drop data were taken. Inshell yield, indexed to trunk cross-sectional area, was also assessed.

\section{Analysis}

The $\mathrm{K}$ concentration of fruit and foliage was determined annually from leaf samples collected from individual trees in mid-July by standard sampling methods with samples collected from all four cardinal directions of the midcanopy. Individual samples were briefly rinsed in dilute acetic acid and deionized water (Smith and Storey, 1976), ovendried at $55^{\circ} \mathrm{C}$ to a constant weight, ground, and stored in airtight containers until analysis. Samples ( $0.5 \mathrm{~g}$ dry weight) were ashed at $500{ }^{\circ} \mathrm{C}$, dissolved in $20 \%$ nitric acid (TraceSelect; Sigma-Aldrich, St. Louis, MO), and diluted with $2 \%$ nitric acid to $50 \mathrm{~mL}$. Aliquots were then appropriately diluted and analyzed for $\mathrm{K}$ using a Perkin Elmer AAnalyst-200 Atomic Absorption Spectrophotometer (Concord, Ontario, Canada) with a K-Lumina-lamp.

\section{Data analysis}

Both studies were analyzed through linear or curvilinear regression analysis when variables were continuous and through analysis

Table 1. Soil characteristics of two 'Desirable' pecan orchards before implementation of the present study involving application of potash (potassium) through a narrow concentrated band to the orchard floor over drip irrigation lines on each side of trees. ${ }^{z}$

\begin{tabular}{|c|c|c|c|c|c|c|c|c|c|c|c|c|}
\hline $\begin{array}{l}\text { Soil depth } \\
\text { (cm) }\end{array}$ & $\mathrm{pH}$ & $\begin{array}{c}\text { Cation } \\
\text { exchange capacity } \\
(\mathrm{meq} / 100 \mathrm{~g})\end{array}$ & $\begin{array}{c}\text { Phosphorus } \\
\left(\mathrm{kg} \cdot \mathrm{ha}^{-1}\right)\end{array}$ & $\begin{array}{c}\text { Potassium } \\
\left(\mathrm{kg} \cdot \mathrm{ha}^{-1}\right)\end{array}$ & $\begin{array}{c}\text { Magnesium } \\
\left(\mathrm{kg} \cdot \mathrm{ha}^{-1}\right)\end{array}$ & $\begin{array}{l}\text { Calcium } \\
\left(\mathrm{kg} \cdot \mathrm{ha}^{-1}\right)\end{array}$ & $\begin{array}{c}\text { Boron } \\
\left(\mathrm{kg} \cdot \mathrm{ha}^{-1}\right)\end{array}$ & $\begin{array}{c}\text { Zinc } \\
\left(\mathrm{kg} \cdot \mathrm{ha}^{-1}\right)\end{array}$ & $\begin{array}{c}\text { Manganese } \\
\left(\mathrm{kg} \cdot \mathrm{ha}^{-1}\right)\end{array}$ & $\begin{array}{c}\text { Iron } \\
\left(\mathrm{kg} \cdot \mathrm{ha}^{-1}\right)\end{array}$ & $\begin{array}{c}\text { Copper } \\
\left(\mathrm{kg} \cdot \mathrm{ha}^{-1}\right)\end{array}$ & $\begin{array}{c}\text { Nickel } \\
\left(\mathrm{kg} \cdot \mathrm{ha}^{-1}\right)\end{array}$ \\
\hline \multicolumn{13}{|c|}{ Study 1} \\
\hline $0-2.5$ & 6.2 & 8.6 & $108 \mathrm{~A}^{\mathrm{y}}$ & $266 \mathrm{H}$ & $312 \mathrm{VH}$ & $1428 \mathrm{VH}$ & $1.8 \mathrm{H}$ & $76 \mathrm{VH}$ & $94 \mathrm{VH}$ & $14 \mathrm{~A}$ & $1.2 \mathrm{M}$ & $1.2^{\mathrm{x}}$ \\
\hline $5.2-10.2$ & 5.6 & 5.0 & $54 \mathrm{~A}$ & $64 \mathrm{~A}$ & $88 \mathrm{M}$ & $526 \mathrm{M}$ & $1.0 \mathrm{M}$ & $21 \mathrm{VH}$ & $60 \mathrm{VH}$ & $28 \mathrm{H}$ & $0.8 \mathrm{~L}$ & 0.6 \\
\hline $10.3-0.3$ & 5.8 & 4.5 & $192 \mathrm{~L}$ & $192 \mathrm{~A}$ & $94 \mathrm{M}$ & $510 \mathrm{M}$ & $1.0 \mathrm{M}$ & $8 \mathrm{H}$ & $60 \mathrm{VH}$ & $34 \mathrm{~A}$ & $0.6 \mathrm{~L}$ & 0.6 \\
\hline \multicolumn{13}{|c|}{ Study 2} \\
\hline $5.2-10.2$ & 6.6 & 13.9 & $132 \mathrm{H}$ & $424 \mathrm{VH}$ & $494 \mathrm{VH}$ & $2412 \mathrm{VH}$ & $2.2 \mathrm{VH}$ & $32 \mathrm{VH}$ & $66 \mathrm{VH}$ & $54 \mathrm{VH}$ & $1.2 \mathrm{~L}$ & 0.6 \\
\hline $10.3-20.3$ & 6.5 & 11.3 & $46 \mathrm{M}$ & $416 \mathrm{VH}$ & $352 \mathrm{H}$ & $1420 \mathrm{H}$ & $1.8 \mathrm{H}$ & $18 \mathrm{VH}$ & $50 \mathrm{VH}$ & $12 \mathrm{~A}$ & $1.2 \mathrm{~L}$ & 0.6 \\
\hline
\end{tabular}

${ }^{\mathrm{z}}$ Trees in Study 1 and Study 2, both commercial orchards, had a history of substantial Stage II fruit drop.

${ }^{\mathrm{y}}$ According to Georgia Extension Service recommendations: $\mathrm{L}=$ low, $\mathrm{M}=$ medium, $\mathrm{A}=$ adequate, $\mathrm{H}=$ high, $\mathrm{VH}=$ very high.

${ }^{\mathrm{x}}$ Standards not yet established. 
of variance when variables were discrete. The alpha level for all statistical tests was $\leq 0.05$ using JMP statistical software (JMP-SAS, Cary, NC).

\section{Results and Discussion}

Because potash treatments, in reality applied both $\mathrm{K}$ and chlorine $(\mathrm{Cl})$, it is not possible to positively attribute observed responses entirely to either $\mathrm{K}$ or $\mathrm{Cl}$, to exclude the possibility of interactions, or to exclude biological activity by trace contaminants. However, the authors conclude that the observed responses to potash banding are most likely attributable to $\mathrm{K}$ in that 1) $\mathrm{Cl}$ is seldom, if ever, deficient in plants; 2) there has never been an observation or report of $\mathrm{Cl}$ deficiency in pecan; 3 ) trees in the southeastern United States typically receive sufficient $\mathrm{Cl}$ through Cl-contaminated precipitation; 4) $\mathrm{K}$ deficiency is common in pecan; 5) similar yield responses to $K$ fertilizers have been reported; and 6) $\mathrm{K}$ is known to greatly influence physiological processes linked to fruit growth, abortion, and abscission. Thus, the following discussion is within the context that the potash response is primarily, if not exclusively, linked to $\mathrm{K}$.

Soil analysis of both orchards indicates that either "high" or "very high" levels of soil K exist in association with "very high" levels of both $\mathrm{Ca}$ and $\mathrm{Mg}$ (Table 1). The upper zone of soil from Study 2 contained approximately twice the amount of $\mathrm{K}, \mathrm{Ca}$, $\mathrm{Mg}$, and zinc than that of Study 1 and also contained high amounts of manganese, iron, and boron. The Study 2 orchard also possessed very high levels of these elements in zones as deep as $20 \mathrm{~cm}$, thus showing evidence of excessive fertilization during 1 or more previous years. The very high amounts of $\mathrm{Ca}$ and $\mathrm{Mg}$ in Study 1 were localized in the upper $2.5 \mathrm{~cm}$ of soil. Considering the potential antagonisms among $\mathrm{K}^{+}, \mathrm{Mg}^{2+}$, and $\mathrm{Ca}^{2+}$, in relation to root uptake from soil solutions and movement of $\mathrm{K}^{+}$across membranes (Epstein and Bloom, 2005; Mengel, 2007), these "very high" levels of alkali earth metals possess potential to either suppress $\mathrm{K}^{+}$uptake or timely in planta $\mathrm{K}^{+}$availability, thus supporting the hypothesis that timely $\mathrm{K}^{+}$availability is contributing to excessive Stage II drop.

Fruit drop patterns. Fruit dropping from trees during the Stage II drop phase had an approximately fourfold greater chance of dropping from the basal-most position within the fruit cluster than from the apical-most position within the fruit clusters (Fig. 1). Additionally, regardless of where aborting fruit originate within the fruit cluster, such fruit were always smaller at time of abscission in mid-June than were other fruit within the cluster retained through the Stage II drop phase (Fig. 2). These smaller fruit were easily dislodged in mid-June with gentle pressure from touching, whereas larger normal fruit were firmly affixed to the peduncle. These touch-sensitive smaller fruit appear to stop growing $\approx 5$ to $7 \mathrm{~d}$ before abscission. When small insect pins are inserted into the nuclear endosperm chamber of young fruit, they abscise 5 to $7 \mathrm{~d}$ after injury (B.W. Wood and W.L. Tedders, unpublished observations), thus indicating that abortion of these small fruit is likely triggered 5 to $7 \mathrm{~d}$ before abscission from the supporting peduncle of the mother fruit cluster.

Stage II fruit drop varied depending on canopy location with retention being substantially greater in the upper one-third than in the lower one-third of the canopy, i.e., more fruit drop per cluster occurring when in the lower canopy (Fig. 3A). Additionally, there was also a canopy associated difference regarding frequency of "totally blank" (i.e., no fruit retained on peduncles by cessation of Stage II drop) with frequency being approximately fourfold greater in the lower onethird of the canopy than in the upper one-third (Fig. 3B). It is noteworthy that trees were well spaced with lower canopies receiving considerable sunlight and lower canopy limbs not exhibiting evidence of excessive shading.

Potassium in fruit and foliage. In Study 1 , the $\mathrm{K}$ concentration of first-season fruit and foliage increased with amount of soil-banded potash applied (Fig. 4). The mean concentration (dry weight basis) in foliage increased from $\approx 1.05 \%$ to $1.17 \%$ when individual trees received $18 \mathrm{~kg}$ of $\mathrm{K}$ as potash with foliage of certain trees elevated to $\approx 1.3 \%$. Under conditions of this study, it is possible to increase foliar $\mathrm{K}$ concentration as a consequence of soil banding; however, the magnitude of increase is small relative to the amount of $\mathrm{K}$ applied to the soil beneath each tree. For comparison, the leaf $\mathrm{K}$ requirement, established by most extension service recommendations, for managing to avoid visual symptoms is greater than $0.75 \% \mathrm{~K}$ with visible foliar $\mathrm{K}$ deficiency symptoms being exhibited at less than $0.60 \% \mathrm{~K}$. Concentrations are set higher for optimum nut yields.

Potash banding also increased fruit-associated $\mathrm{K}$ concentration in retained fruit with mean $\mathrm{K}$ concentration being $\approx 1.5 \%$ at the highest $\mathrm{K}$ treatment (with some individuals up to $\approx 1.75 \% \mathrm{~K}$ ). The total concentration of

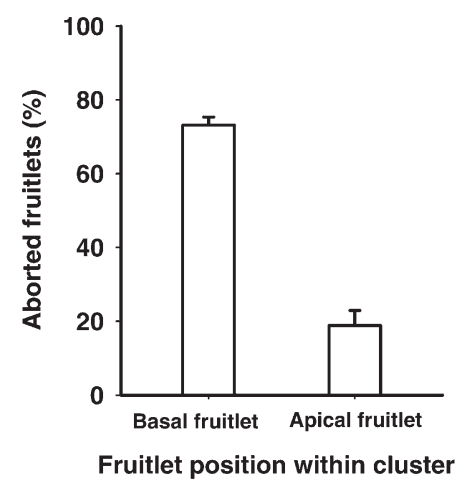

Fig. 1. Position of dropped fruit within 'Desirable' fruit clusters as a consequence of Stage II fruit drop. Bars represent percentage of aborted fruit with SEs. "Basal" refers to the basal-most fruit of the cluster, whereas "apical" refers to the apical-most fruit within the cluster.
$\mathrm{K}$ in healthy retained fruit was $\approx 0.25 \%$ to $0.30 \% \mathrm{~K} /$ dry weight greater than that of foliage, regardless of potash treatment; thus, young developing fruit appear to require a substantially higher $\mathrm{K}$ concentration than foliage. Conversely, the $\mathrm{K}$ concentration in abscised fruit was substantially less $-0.2 \%$ to $0.4 \%$ less - than that of retained fruit, and the amount of soil-banded potash did not influence $\mathrm{K}$ concentration in dropped fruit. This indicates a relationship between aborted fruit and $\mathrm{K}$ concentration and implies that if the $\mathrm{K}$ concentration of young fruit is $\approx 1.25 \%$ or less at this stage of fruit development (i.e., before the log phase of fruit growth), then there is a much greater likelihood of abortion and abscission; thus, under circumstances of the present study, maintaining the $\mathrm{K}$ concentration of fruit at $\approx 1.25 \%$ or greater appears to contribute to reducing Stage II drop of developing fruit.

A similar relationship also occurred in the second orchard (Study 2) possessing very high
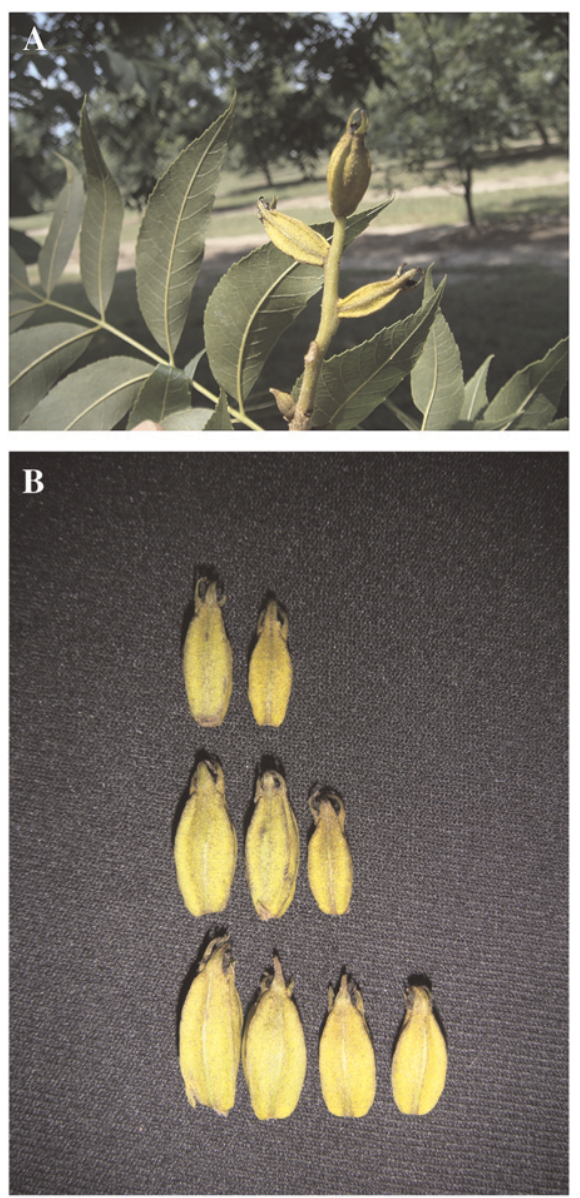

Fig. 2. Fruit dropping during Stage II drop were typically the smallest fruit within the fruit cluster and often the basal-most fruit within the cluster. (A) The basal-most fruit are the smallest in the cluster and drops on gentle touching. (B) The fruit within each of the three rows of fruit in the figure represent fruit within an individual nut cluster of different sizes (i.e., two, three, and four fruit per cluster) with the fruit on the far right being the fruit that abscised on slight touch with the finger. 
soil $\mathrm{Ca}$ and $\mathrm{Mg}$ with abscised fruit possessing a $\mathrm{K}$ concentration substantially lower than retained fruit (Fig. 5) with the mean difference between the two being $\approx 0.5 \% \mathrm{~K}$. In this study, increasing potash $\mathrm{K}$ only slightly affected $\mathrm{K}$ concentration of retained fruit but

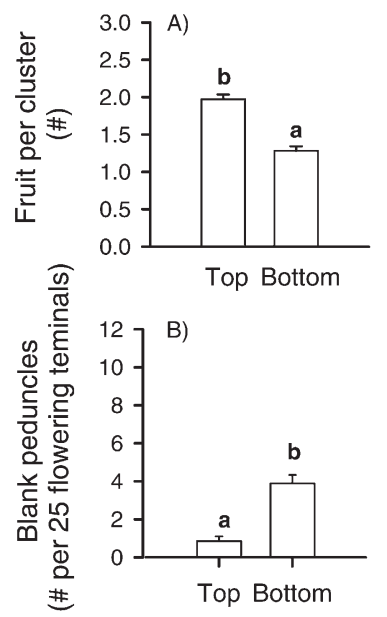

Position of cluster within canopy

Fig. 3. Number of 'Desirable' fruit per cluster and number of "blank" peduncles after Stage II drop as a function of position within the tree canopy. The test orchard is a commercial 'Desirable" orchard. "Top" is the upper one-third of the canopy; whereas "bottom" is the lower one-third of the canopy. All sampled clusters were from sun-exposed terminals. Means are significantly different at $P \leq 0.001$ by analysis of variance.

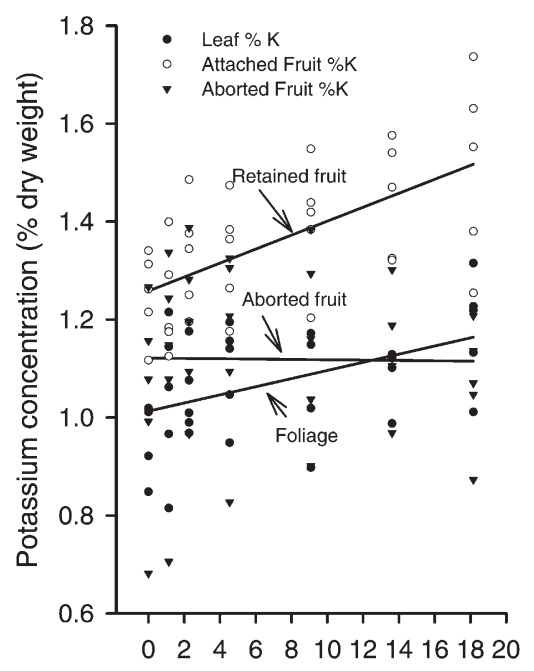

Potassium applied as soil band (kg.tree $\left.{ }^{-1}\right)$

Fig. 4. Influence of soil-banded potassium (K) treatments from potash on $\mathrm{K}$ concentration of "retained" or "abscised" fruit and in foliage of 'Desirable' the first year after potash application in an orchard possessing low foliar $\mathrm{K}$ (Study 1). Linear regression for "retained" fruit is such that " $\% \mathrm{~K}=1.013+0.0083 x "$ $\left(R^{2}=0.22, \alpha=0.05\right)$; "abscised" fruit $=1.121$ - 0003x $\left(R^{2}=0.006\right.$, nonsignificant $) ;$ and "foliage" " $\% \mathrm{~K}=1.258+0.0142 x "\left(R^{2}=\right.$ $0.38, \alpha=0.05$ ). substantially impacted foliage (i.e., increasing mean content from $1.12 \%$ to $1.40 \% \mathrm{~K}$ ); hence, from the standpoint of added $\mathrm{K}$ through fertilization, foliage in this particular orchard situation apparently acted as a stronger $\mathrm{K}$ sink than did fruit. Perhaps this is because the relatively high $1.58 \%$ to $1.62 \% \mathrm{~K}$ concentration of fruit is near optimum for fruit at this particular stage of development, and there was no physiological need to accumulate $\mathrm{K}$ at higher concentrations; yet, for an unknown reason, fruit that eventually dropped did not accumulate nearly as much $\mathrm{K}$. This is taken as evidence that in addition to $\mathrm{K}$, there are potentially one or more other stress factors influencing Stage II drop.

Influence of potash on fruit retention. In Study 1, increasing the amount of banded potash per tree increased fruit retention in both the first growing season of treatment (2006) and in the third season after treatment (2008) (Fig. 6). The impact of potash banding on fruit retention was substantial the first year but declined by the third year post-treatment. In Study 2, potash banding also increased fruit retention; yet, retention diminished the second year post-treatment (Fig. 7). Retention of fruit during the first year post-treatment was approximately twofold greater than the control when treated trees received potash equating to $18 \mathrm{~kg} \mathrm{~K}$ per tree.

Influence of potash on in-shell yield and quality. In Study 1, potash banding increased in-shell yield of 'Desirable' trees the first growing season with yield increasing curvi-

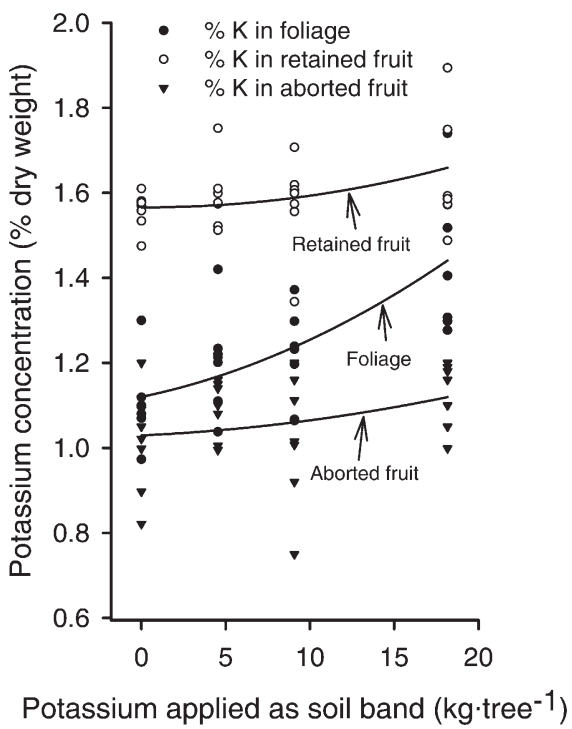

Fig. 5. Influence of soil-banded potassium (K) treatments from potash on $\mathrm{K}$ concentration of "retained" or "abscised" fruit and in foliage of 'Desirable' the first year after potash application in an orchard possessing foliar $\mathrm{K}$ less than that recommended by the Georgia Extension Service (Study 2) but higher than that of the orchard in Study 1 (Fig. 4). Curvilinear regression for "retained" fruit is such that " $\% \mathrm{~K}=$ $1.556-0.0002 x+0.0003 x^{2} "\left(R^{2}=0.14, \alpha=\right.$ $0.05)$; "abscised" fruit $=1.029+0.002 x+$ $0.0002 x^{2}\left(R^{2}=0.09, \alpha=0.05\right)$; and "foliage" "\% $\mathrm{K}=1.12+0.008 x+0001 x^{2} "\left(R^{2}=0.38, \alpha=\right.$ $0.05)$. linearly as potash increased (Fig. 8). There was also increased kernel quality as amount of potash increased (Fig. 9). Banding potash at $\approx 18 \mathrm{~kg}$ of $\mathrm{K}$ per tree resulted in an $\approx$ 3 -point increase in kernel percent (i.e., a quality trait) as tree yield also increased compared with no additional $\mathrm{K}$. This increase in in-shell tree yield, as a consequence of potash banding, persisted at a diminished level into at least the third year post-treatment. There was no effect of $\mathrm{K}$ banding on percent kernel by the third year post-treatment (Fig. 9). There was no detected influence of potash on nut size (data not presented). These results indicate that, in this particular orchard situation, potash fertilization through banding, although foliar $\mathrm{K}$ was within the sufficiency

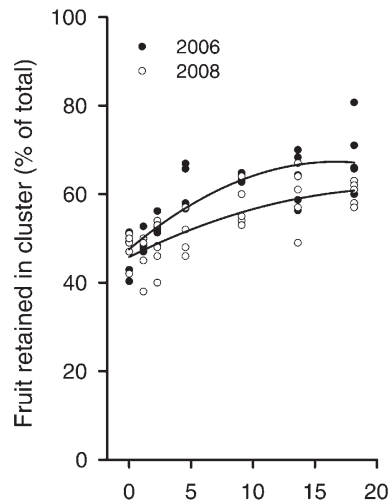

Potassium applied as soil band $\left(\mathrm{kg}^{\text {tree }}{ }^{-1}\right)$

Fig. 6. Influence of soil-banded potassium (K) treatments from potash on fruit retention after Stage II drop of 'Desirable' in a research orchard the first and third growing season after application. Quadratic regression for fruit retention is " $2006 \%$ Retention" $=47.56+2.36 x$ $-0.078 x^{2}\left(R^{2}=0.71, \alpha=0.05\right) ; " 2008 \%$ Retention" $=45.78+1.40 x-0.0317 x^{2}\left(R^{2}=\right.$ $0.59, \alpha=0.05)$.

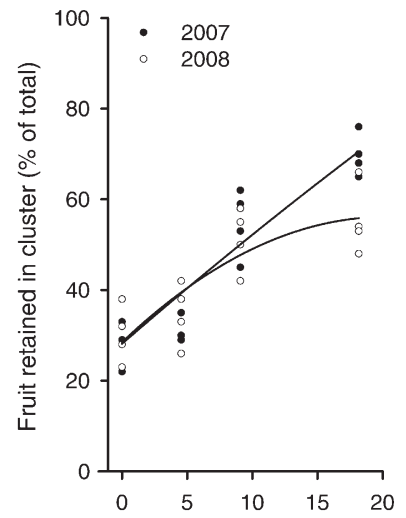

Potassium applied as soil band $\left(\mathrm{kg} \cdot \mathrm{tree}^{-1}\right)$

Fig. 7. Influence of soil-banded potassium (K) treatments from potash on fruit retention after Stage II drop of 'Desirable' in a commercial orchard the first and second growing season after application. Quadratic regression for fruit retention is " $2007 \%$ Retention" $=28.15+$ $2.489 x-0.00854 x^{2}\left(R^{2}=0.85, \alpha=0.05\right)$; "2008 \% Retention" $=28.48+2.728 x-$ $0.0672 x^{2}\left(R^{2}=0.69, \alpha=0.05\right)$. 
range for pecan, increased in-shell nut yield, kernel quality, fruit retention, $\mathrm{K}$ concentration in foliage and fruit, and fruit retention. Hence, yield components of this particular orchard, which was judged by foliage analysis to have been K-sufficient, were clearly limited by one or more factors at least partially overcome by potash banding. Unfortunately, the benefit of banded potash had largely diminished by the third year posttreatment.

In Study 2, in which tree leaf analysis indicated that tree $\mathrm{K}$ nutrition was well within the sufficiency range, banded potash increased

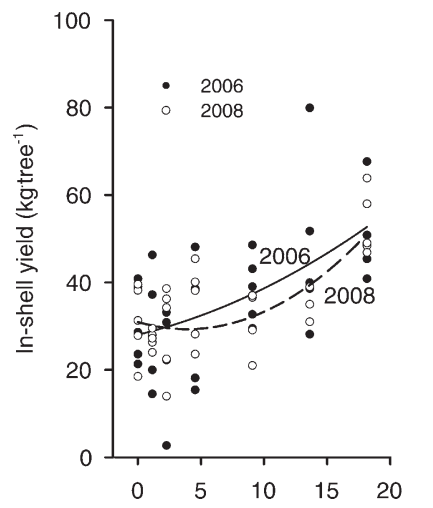

Potassium applied as soil band (kg.tree ${ }^{-1}$ )

Fig. 8. Influence of soil-banded potassium (K) treatments from potash on in-shell nut yield (i.e., $\mathrm{kg}$ per tree) the first (2006) and third (2008) growing season after $\mathrm{K}$ application in a research orchard. Curvilinear regression for "in-shell nut yield per tree" $=28.04+$ $0.698 x+0.00363 x^{2}\left(R^{2}=0.34, \alpha \leq 0.01\right)$ during the first crop post-treatment. Curvilinear regression for "in-shell nut yield per tree" = $30.93-0.832 x+0.017 x^{2}\left(R^{2}=0.51, \alpha \leq 0.01\right)$ during the third crop post-treatment.

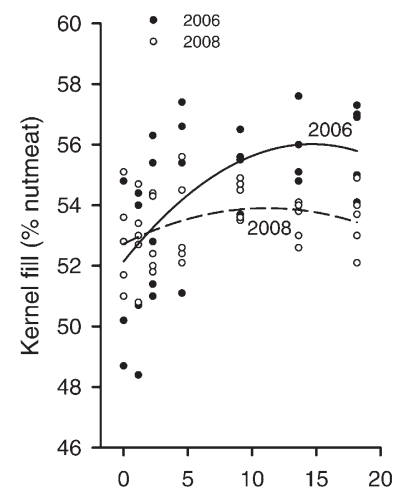

Potassium applied as soil band $\left(\mathrm{kg} \cdot \mathrm{tree}^{-1}\right)$

Fig. 9. Influence of soil-banded potassium (K) treatments from potash on kernel quality (i.e., percentage nutmeat) the first (2006) and third (2008) growing seasons after $\mathrm{K}$ application in a research orchard. Curvilinear regression for "Kernel fill" $=52.15+0.529 x+0.018 x^{2}\left(R^{2}=\right.$ $0.35, \alpha \leq 0.01)$ during the first crop posttreatment. Curvilinear regression for "Kernel fill" $=52.72+0.212 x+0.009 x^{2}\left(R^{2}=0.11\right.$, nonsignificant) during the third crop post-treatment. tree in-shell nut yield (based on trunk crosssectional area), as exhibited in Study 1 (Fig. 10 ). Trees receiving $\mathrm{K}$ at $\approx 18 \mathrm{~kg}$ per tree produced roughly $41 \%$ more in-shell yield than the control during the first season posttreatment (an "off" year) and $\approx 44 \%$ the second season post-treatment (an "on" year). This yield increase was not the result of a detectable increase in percentage kernel as a consequence of $\mathrm{K}$ banding as was observed in Study 1 (Figs. 9 and 11). Percentage kernel averaged $\approx 55 \%$ in the "off" year and $\approx 52 \%$ during the "on" year, thus reflecting the usual effect of diminished kernel percent as crop load increases. Results from Study 2 reflect a second case in which potash banding acted

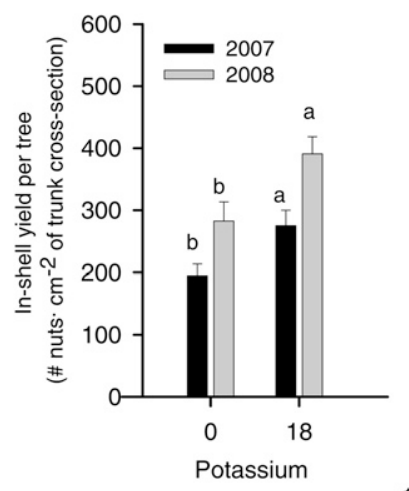

[applied as soil band $\left(\mathrm{kg} \cdot \mathrm{tree}^{-1}\right)$ ]

Fig. 10. Influence of soil-banded potassium (K) treatments from potash on in-shell nut yield (i.e., number of nuts per $\mathrm{cm}^{2}$ of trunk crosssectional area) the first and second growing seasons after $\mathrm{K}$ application in a commercial orchard. Treatments are: $\mathrm{K}$ applied as potash with actual $\mathrm{K}$ at 0 and $18 \mathrm{~kg} /$ tree in Mar. 2007. Bars are SEs. Letters represent statistical differences at $\alpha \leq 0.02$ by analysis of variance with different letters between $\mathrm{K}$ treatments, within a year, being different.

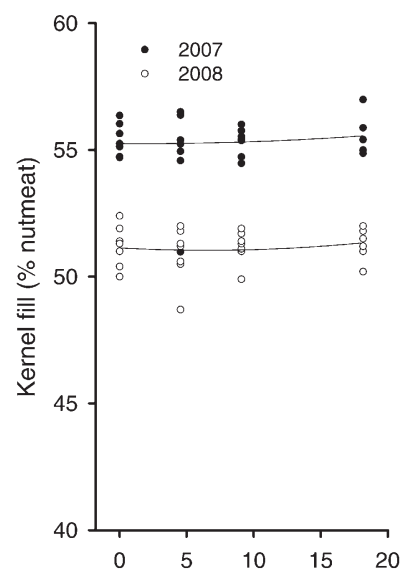

Potassium applied as soil band $\left(\mathrm{kg} \cdot \mathrm{tree}^{-1}\right)$

Fig. 11. Influence of soil-banded potassium (K) treatments from potash on kernel percentage of ripe nuts of 'Desirable' in a commercial orchard the first and second growing seasons after application. Quadratic regressions for fruit retention are nonsignificant. to increase nut yields in a 'Desirable' orchard that appeared to have been K-sufficient.

Influence of soil potassium banding. Intensively managed orchard trees growing on many soils in the southeastern United States pecan belt often exhibit $\mathrm{K}$ deficiency with foliar $\mathrm{K}$ concentration being poorly correlated with soil K content (Worley, 1972). The low soil $\mathrm{K}$ content of the region's highly leached marine sediments and high soil $\mathrm{Al}^{3+}$ greatly limits $\mathrm{K}$ availability. Additionally, many middle south soils possess low $\mathrm{K}$ because they are derived from highly weathered igneous, sedimentary, or metamorphic rocks. Although certain U.S. soils typically contain relatively high amounts of $\mathrm{K}$, its availability for root uptake is low as a result of excessive soil $\mathrm{Ca}^{2+}$ and $\mathrm{Mg}^{2+}$. Potassium uptake is also adversely affected by excessive soil N, P, Ca, $\mathrm{Mg}$, and sulfur (Sparks, 1985). Orchard K stress is further increased as a result of orchard management practices that encourage rapid tree growth (e.g., high $\mathrm{N}$ and an abundance of water) in an effort to maximize nut yield.

The $\mathrm{K}$ sufficiency recommendation for optimum nut production of pecan orchards varies among U.S. states but is usually $\approx 1.25 \%$ to $1.5 \%$ (Smith, 1991; Wells and Wood, 2007) for early to midsummer foliage of commercial orchards. It is set at $1.25 \%$ to $2.50 \% \mathrm{~K}$ for optimum production in Georgia (Plank, 1988). Cultural practices for managing orchard leaflet $\mathrm{K}$ concentration at this targeted concentration range are often unsuccessful as a result of adsorption of fertilizer-supplied $\mathrm{K}$ to soil clay particles and subsequent reduced availability for root uptake. Additionally, many southeastern soils contain a substantial percentage of clay minerals (i.e., illite, vermiculite, and chlorite) that fix applied $\mathrm{K}$ to relatively non-exchangeable sites; thus, orchard trees often exhibit little or no response to soil-applied $\mathrm{K}$ fertilizers. Also, because many orchard soils in the southeastern United States are poorly irrigated during the early stages of fruit development during May and June, trees have difficulty absorbing sufficient $\mathrm{K}$ from dry soils.

Application to soils of a concentrated band of soluble potash apparently increases $\mathrm{K}^{+}$diffusion and mass flow to feeder roots, especially those near irrigation emitters. Thus, the present study indicates that potash banding appears to be a viable means for improving tree $\mathrm{K}$ nutrition and nutmeat yield and quality in certain orchard situations for at least 2 years after banding. Other possible benefits of improved $\mathrm{K}$ nutrition through banding are 1) increased tolerance to winter cold injury (Sharpe et al., 1952; Wood, 1986); 2) improved leaf health (Sparks, 1976a, 1976b); 3) reduced water-stage fruit split (Wood and Reilly, 1999) and reduced vivipary (preharvest sprouting) (Zertucke and Storey, 1983); and 4) improved oil content of kernels (Hunter and Hammar, 1952, 1957).

It has been postulated, based on work by Hunter (1951) and Skinner (1922), that K fertilization of pecan orchards affects kernel development more than does either $\mathrm{N}$ or $\mathrm{P}$ 
fertilization (Sparks, 1985); thus, it is usually expected that soil $\mathrm{K}$ application will increase orchard yields. However, based on field studies by Gossard and Hammar (1962), Hunter (1951), Hunter and Hammar (1952, 1957), and Worley (1974, 1994), K application to orchards has only shown trends toward increasing nutmeat yield and quality (i.e., percentage kernel). The present study appears to be the first example of a statistically significant increase in pecan fruit retention or nutmeat yield and quality as a consequence of $\mathrm{K}$ fertilization of pecan orchard soils. The increased kernel percentage of individual nuts observed here, as a consequence of elevating tree $\mathrm{K}$, is consistent with conclusions by Pe'er and Kessler (1984) that K plays a key role in the biosynthesis of lipids within pecan meats. Perhaps a high kernel percentage is because a relatively high foliar $\mathrm{K}$ concentration is required for adequate timely translocation of assimilates to the developing cotyledons (Mengel, 2007). Results from the two orchards described in the present study indicate that (in cases where orchard soils possess excessively high soil $\mathrm{Mg}$ and $\mathrm{Ca}$ ), potash banding can improve yield components in orchards identified as K-sufficient based on leaf analysis. Perhaps a superior alternative approach to supplying tree $\mathrm{K}$ needs is through fertigation; hence, there is merit in further research comparing cost-effectiveness and efficacy of the two approaches.

Influence of potassium on fruit drop. Potassium is generally the most abundant mineral cation in plants, but for pecan foliage, it is typically present at concentrations less than either $\mathrm{Ca}$ or $\mathrm{Mg}$. As the primary cationic osmoticum of cells and a key stabilizer/activator of certain key enzymes, a localized transient shortage in developing fruit might conceivably contributes to fruit abortion and/or abscission. Additionally, this outcome might also arise if cytoplasmic $\mathrm{K}$ concentration is insufficient for activation (usually greater than 50 to $130 \mathrm{~mm} \mathrm{~K}$ ) of any one of dozens of low $\mathrm{K}$ affinity, but K-requiring, enzymes. Considering the critical role of $\mathrm{K}$ as a counterion in membrane transport of other nutrient elements, anion neutralization, and maintenance of $\psi_{\mathrm{S}}$, it is entirely feasible that the apparent positive effect of $\mathrm{K}$ in these orchards is linked to transport of other elements, especially micronutrients required for activation and/or structure of any one of a host of key enzymes.

Developing pecan fruit potentially compete with foliage for available $\mathrm{K}$ taken up by roots. Once foliar growth stops, fruit begin rapid growth with variable amounts of leaf $\mathrm{K}$ remobilized to developing fruit (Smith, 2009). This rapid fruit growth usually begins $\approx 70 \mathrm{~d}$ post-pollination and extends to $\approx 140$ to $160 \mathrm{~d}$ post-pollination depending on genotype. Fruit growth is relatively slow during the first $\approx 60 \mathrm{~d}$ of development, accumulating little dry weight. Thus, young fruit growing in late spring are weak $\mathrm{K}$ competitors relative to rapidly growing vegetative organs (Sparks, 1985). It is therefore possible that under K stress conditions, low-K vegetative organs are stronger competitors for available $\mathrm{K}$ than are young fruit, hence potentially disrupting fruit associated physiological processes sufficient to trigger fruit abscission. This possibility is supported by the data in Figures 4 and 5 in that the $\mathrm{K}$ concentration in aborted fruit did not increase with increasing amounts of $\mathrm{K}$ fertilizer as did non-aborting fruit and foliage. Foliar K concentration typically increases up to the initiation of rapid fruit growth with accumulation rate diminishing to zero just before onset of rapid fruit growth (Smith, 2009). Because late-season fruit development can trigger $\mathrm{K}$ deficiency in adjacent foliage, it is likely that early-season canopy development similarly triggers $\mathrm{K}$ deficiency in young slow-growing fruit during late spring.

Our observation that the smallest fruit within clusters are the individuals most likely to abort during the Stage II drop period supports similar observations by Yates and Sparks (1994, 1995). This is consistent with K deficiency in that the initial visible stage of $\mathrm{K}$ deficiency is growth retardation (Mengel, 2007); however, visual observations failed to indicate any clear evidence of $\mathrm{K}$ deficiency symptoms occurring in basal leaflets of associated compound leaves and shoots. The observation that elevation of fruit $\mathrm{K}$ concentration reduces fruit drop implies a regulatory role for $\mathrm{K}$ in regard to abscission physiology with an endogenous fruit concentration of $\approx 1.25 \% \mathrm{~K}$ or less during the period between floral fertilization and Stage II drop being the approximate threshold for triggering premature drop of 'Desirable' fruit. This K-fruitabscission relationship is consistent with observations of a positive linear relationship between $\mathrm{K}$ in shuck tissue and in lipids within developing kernels (Pe'er and Kessler, 1984). Pe'er and Kessler (1984) proposed that in the case of 'Delmas', $1.57 \% \mathrm{~K}$ was a critical shuck tissue $\mathrm{K}$ concentration required for optimal fruit development. There is substantial variation among cultivars in regard to the percentage of fruit that abort in association with Stage II drop (Worley, 1995); thus, the proposed $\mathrm{K}$ drop threshold of $\approx 1.25 \%$ may well differ among cultivars and may be lower in cultivars with abnormally high Stage II drop (e.g., Oconee, Owens, Gloria Grande, Stuart). Alternatively, the difference in sensitivity may be the result of the ability of fruit to compete with foliage for available $\mathrm{K}^{+}$ during late spring fruit development. This is consistent with observations by Smith (1982) that fruit drop is greater on 'Western Schley' shoots supporting substantial leaf area, where shoots could potentially be stronger $\mathrm{K}^{+}$sinks, than on shoots supporting less leaf area.

A regulatory role for $\mathrm{K}$ in regard to fruit growth is also supported in that passive $\mathrm{K}^{+}$uptake by roots is indirectly and tightly linked to tree metabolic activity with $\mathrm{K}^{+}$being highly mobile in both the xylem and phloem (Marschner, 2002). Thus, if insufficient fruit $\mathrm{K}^{+}$contributes to Stage II fruit drop, then substantially increasing soil solution $\mathrm{K}^{+}$availability is likely to reduce $\mathrm{K}^{+}$ stress of developing fruit and reduce fruit drop, therefore increasing yield, kernel quality, and tree health. Worley (1994) concluded that in the case of a non-irrigated pecan orchard, managing trees based on a foliar $\mathrm{K}$ threshold of $0.75 \%$ was adequate for commercial production on 'Stuart' pecans; however, in light of data here, this appears unlikely to be true for irrigated 'Desirable'. Additionally, anecdotal evidence indicates that growers managing orchards at $1.5 \% \mathrm{~K}$ or greater (i.e., probably exceeding $1.25 \% \mathrm{~K}$ in young fruit) in foliage typically have higher in-shell and nutmeat yields.

Young pecan fruit and associated expanding foliar and shoot organs are strong competitive sinks for available $\mathrm{K}^{+}$(Sparks, 1977), especially when one considers that $\mathrm{K}^{+}$is the most abundant ( $\approx 100$ to $150 \mathrm{~mm}$ ) cytoplasmic cation in expanding cells (Epstein and Bloom, 2005). This competition appears to limit K movement into young slowly growing fruit wherever an increasing amount of $\mathrm{K}$ is likely needed for protein synthesis, enzyme activation, photosynthesis, osmoregulation, cell expansion, synthesis of carbohydrates and lipids, and turgor regulation. Additionally, because $\mathrm{K}^{+}$uptake by roots is potentially reduced by excessive soil $\mathrm{Ca}^{2+}$ and $\mathrm{Mg}^{2+}$ (Mengel, 2007) and $\mathrm{N}$ (Sparks and Baker, 1975), there is the possibility that the high $\mathrm{Ca}$ and $\mathrm{Mg}$ content of the upper soil zone of both test orchards, plus substantial $\mathrm{N}$ fertilization, contributed to insufficient fruit $\mathrm{K}$ and subsequent abscission. This raises the possibility that Stage II fruit drop in 'Desirable' pecan is, at least in certain cases, the result of an interaction between soil $\mathrm{K}$ availability and competing sink strength for available K.

\section{Conclusion}

It was demonstrated that increasing $\mathrm{K}$ nutrition of trees identified as K-sufficient, based on leaf analysis standards, can increase nutmeat yield and quality and reduce fruit drop in certain 'Desirable' pecan orchards. It appears that $\mathrm{K}$ stress of young developing fruit can potentially trigger fruit abscission associated with the Stage II drop window when endogenous $\mathrm{K}$ concentration of fruit is $1.25 \%$ dry weight or less (i.e., in 'Desirable'), hence indicating that non-pollination and noninsect-associated Stage II fruit drop might be an early visual symptom of $\mathrm{K}$ deficiency in 'Desirable'. This implies that the foliar-based lower sufficiency level for optimum nutrition of mature bearing orchards might need to be substantially higher than the $0.75 \%$ to $1.25 \%$ foliar K concentration commonly targeted in many orchard operations. Although this standard lower sufficiency range might be appropriate for foliage and shoots, it might be insufficient for normal early growth for fruit of certain cultivars. We conclude that $\mathrm{K} \mathrm{nu}$ trition management of pecan merits further study, because insufficient tree $\mathrm{K}$ nutrition might be triggering excessive fruit drop and limiting orchard yields of high-quality nutmeats more than is commonly supposed. Additionally, it is apparent that in certain soil situations, soil banding of potash in 
a concentrated band above drip irrigation emitters is an effective approach for rapidly increasing foliar $\mathrm{K}$ concentration and therefore merits efficacy trials in commercial orchards.

\section{Literature Cited}

Epstein, E. and R.J. Bloom. 2005. Mineral nutrition of plants: Principles and perspectives. 2nd Ed. Sinauer, Sunderland, MA.

Finch, A.H. and H.L. Crane. 1931. Physiological factors associated with the productiveness of pecan shoots. Proc. Natl. Pecan Assn. Bul. 30:98-107.

Finn, G.A., A.E. Straszewski, and V. Peterson. 2007. A general stage key for describing trees and woody plants. Ann. Appl. Biol. 151:127-131.

Gossard, A.C. 1933. The importance of maintaining vigorous terminal growth on pecan trees. Proc. Natl. Pecan Assn. Bul. 32:84-89.

Gossard, A.C. and H.E. Hammar. 1962. Some effects of potassium fertilization and sod culture on pecan tree performance and nutrition. Proc. Amer. Soc. Hort. Sci. 81:184-193.

Hamilton, J. 1942. Studies of the premature dropping of pecan nuts. Proc. Amer. Soc. Hort. Sci. 40:159-160.

Hudson, W., J. Brock, S. Culpepper, W. Mitchem, and L. Wells. 2009. Georgia pecan pest management guide. Georgia Coop. Ext. Serv. Bul. No. 841.

Hunter, J.H. 1951. Progress report on soil management experiments with pecans. Proc. Southeastern Pecan Growers Assoc. 44:10-17.

Hunter, J.H. and H.E. Hammar. 1952. Influence of cultivation, mulching, and fertilizers on chemical composition of pecan leaves and their relation to yield and quality of nuts. Soil Sci. Proc. 16:346-349.

Hunter, J.H. and H.E. Hammar. 1957. Variation in composition of pecan leaves. Better Crops Plant Food 41:18-25.

Lockwood, D. and D. Sparks. 1978. Translocation of ${ }^{14} \mathrm{C}$ in 'Stuart' pecan in the spring following assimilation of ${ }^{12} \mathrm{CO} 2$ during the previous growing season. J. Amer. Soc. Hort. Sci. 103:38-45.

Marschner, H. 2002. Mineral nutrition of higher plants. 2nd Ed. Academic Press, New York, NY.

Mengel, K. 2007. Potassium, p. 91-144. In: Barker, A.V. and D.J. Pilbeam (eds.). Handbook of plant nutrition. Taylor and Francis, New York, NY.

Pe'er, S. and B. Kessler. 1984. The development of the 'Delmas' pecan fruit, with special reference to growth phases and changes of lipids and potassium. Sci. Hort. 24:323-329.

Plank, C.O. 1988. Plant analysis handbook for Georgia. Ga. Coop. Ext. Serv. 48-49.

Romberg, L.D. and C.L. Smith. 1946. Effects of cross-pollination, self-pollination, and sib-pollination on dropping, the volume, and the kernel development of pecan nuts and on the vigor of the seedlings. Proc. Amer. Soc. Hort. Sci. 47:130-138.

Sharpe, R.H., G.H. Blackmon, and N. Gammon. 1952. Relation of potash and phosphate fertilization to cold injury of Moore pecans. Proc. Southeastern Pecan Growers Assn. 45:81-85.

Skinner, J.J. 1922. Influence of fertilizer on the yield, size and quality of pecan. Proc. Ga-Fl. Pecan Growers Assoc. 16:50-56.

Smith, M.W. 1982. Factors associated with nut abortion in pecan. HortScience 17:147-148.

Smith, M.W. 1991. Pecan nutrition, p. 152-158. In: Wood, B.W. and J.A. Payne (eds.). Pecan husbandry: Challenges and opportunities. First National Pecan Workshop Proceedings, U.S Department of Agriculture. Agricultural Research Service, ARS-96.

Smith, M.W. 2009. Partitioning phosphorous and potassium in pecan trees during high- and lowcrop seasons. J. Amer. Soc. Hort. Sci. 134:399404.

Smith, M.W. and J.B. Storey. 1976. The influence of washing procedures on surface removal and leaching of certain elements from pecan leaflets. HortScience 11:50-52.

Sparks, D. 1976a. Some nutrient deficiency symptoms of pecan. Pecan South 3:264-267.

Sparks, D. 1976b. Nitrogen scorch of pecan. Pecan South 3:500-501.

Sparks, D. 1977. Effects of fruiting on scorch, premature defoliation, and nutrient status of 'Chickasaw' pecan leaves. J. Amer. Soc. Hort. Sci. 102:669-673.

Sparks, D. 1985. Potassium nutrition of pecan, p. 1145-1153. In: Munson, R.D. (ed.). Potassium in agriculture. ASA-CSSA-SSA, Madison, WI.

Sparks, D. 1988. Effect of shoot vigor on pistillate flower production and abortion in 'Stuart' pecan. HortScience 23:570-571.
Sparks, D. and D.H. Baker. 1975. Growth and nutrient response of pecan seedlings, Carya illinoinensis Koch, to nitrogen levels in sand culture. J. Amer. Soc. Hort. Sci. 100:392-399.

Sparks, D. and J.L. Heath. 1972. Pistillate flower and fruit drop of pecan as a function of time and shoot length. HortScience 7:131-132.

Sparks, D. and G.D. Madden. 1985. Pistillate flower and fruit abortion in pecan as a function of cultivar, time, and pollination. J. Amer. Soc. Hort. Sci. 110:219-223.

Sparks, D., W. Reed, I.E. Yates, M.W. Smith, and T.G. Stevenson. 1994. Fruiting stress induces shuck decline and premature germination in pecan. J. Amer. Soc. Hort. Sci. 120:43-53.

Wells, M.L. and B.W. Wood. 2007. Relationships between leaflet nitrogen: Potassium ratio and yield of pecan. HortTechnology 17:473-479.

Wood, B.W. 1986. Cold injury susceptibility of pecan as influenced by cultivar, carbohydrates, and crop load. HortScience 21:285-286.

Wood, B.W., L. Lombardini, and R. Heerema. 2009. Influence of aminoethoxyvinylglycine $(\mathrm{AVG})$ on pecan fruit retention. HortScience 44:1884-1889.

Wood, B.W. and C.C. Reilly. 1999. Factors influencing water split of pecan fruit. HortScience 34:215-217.

Woodruff, J.G., N.C. Woodroof, and J.E. Bailey. 1928. Unfruitfulness of the pecan. Georgia Expt. Sta. Bul. 148.

Worley, R.E. 1972. Fertilizing pecans based on soil tests. Proc. S.E. Pecan Growers Assoc. 65:115120.

Worley, R.E. 1974. Effect of N, P, K, and lime on yield, nut quality, tree growth, and leaf analysis of pecan. J. Amer. Soc. Hort. Sci. 99:49-57.

Worley, R.E. 1994. Long-term performance of pecan trees when potassium application is based on prescribed threshold concentrations in leaf tissue. J. Amer. Soc. Hort. Sci. 119:434-438.

Worley, R.E. 1995. Pecan cultivars differ greatly in susceptibility to June drop. HortScience 30:630.

Yates, I.E. and D. Sparks. 1994. Anatomy differs for aborting and non aborting pistillate flowers in pecan. J. Amer. Soc. Hort. Sci. 119:949-955.

Yates, I.E. and D. Sparks. 1995. Morphology of post pollination fruit abortion in pecan. $\mathrm{J}$. Amer. Soc. Hort. Sci. 120:446-453.

Zertucke, M.I. and J.B. Storey. 1983. Preharvest germination of pecans. HortScience 18:579. 